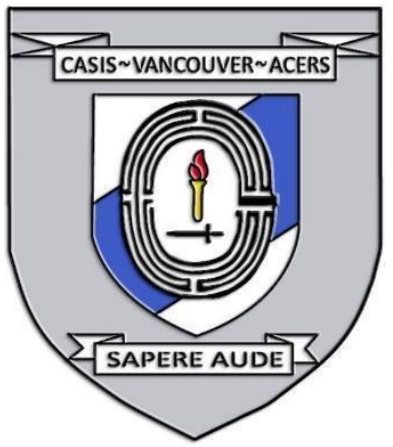

\title{
INTELLIGENCE AND RISKS POSED BY CORRUPTION
}

Date: November $26^{\text {th }}, 2020$

Disclaimer: This briefing note contains the encapsulation of views presented by the speaker and does not exclusively represent the views of the Canadian Association for Security and Intelligence Studies.

\section{KEY EVENTS}

On November 26, 2020, Andrew Dalip presented at the 2020 CASIS West Coast Security Conference, where he spoke about intelligence and corruption. This presentation was followed by a group panel for questions and answers, whereby conference attendees were provided with an opportunity to engage in discussion with Mr. Dalip and other panel presenters for that day. Primary discussion topics included operational concerns for security in Trinidad and Tobago, corruption related to lack of due diligence and reporting, and the limitations for COVID-19 preparation that resulted from corruption in Trinidad and Tobago.

\section{NATURE OF DISCUSSION}

\section{Presentation}

The topic of intelligence and corruption was addressed and focussed on examples of corruption as well as actions that can be made to potentially reduce corruption. The highest corruption perceptions for 2019 existed for locations such as parts of South America, Africa, Asia, and the Caribbean. Mr. Dalip discussed the potential risks corruption poses to foreign operations. Examples of corruption included the US, ISAF, and NATO operations in Afghanistan as well as examples of members of the FBI, CIA, and RCM who possibly engaged in corrupt actions. Mozambique's US $\$ 2.2$ billion secret debt was also examined. Mr. Dalip examined the role of various domestic and international agencies and the potential importance of ensuring implementation of actions by a multitude of agencies, to ensure corruption is actioned appropriately. He focussed his presentation on financial crime, whereby he indicated that due diligence and suspicious transactions reporting is a possible necessity. In addition, record keeping and information sharing hold potential value in addressing corruption. 


\section{Question Period}

During the question period, discussions surrounding global and domestic, Common-Wealth corruption occurred. Additionally, the potential for reconciliation between countries who were historical enemies was mentioned. Conclusively, possible future academic research needed was explained.

\section{BACKGROUND}

\section{Presentation}

Data from Transparency International was presented on Corruption Perceptions Index, 2019, which indicated that parts of Africa, Asia, South America, and the Caribbean had the highest scores for this index. A Common-Wealth perspective was provided through the context of Trinidad \& Tobago. Mr. Dalip discussed that much of the potential lack of preparedness for COVID-19 possibly resulted from probable corruption. Criminal gangs in Trinidad possibly facilitate corruption, as members wait for primetime before they act in a manner that makes corruption possibly thrive. This can likely have an impact on national security. The nature of corruption is not always a top down process, and can sometimes be bottom up, and in the system of Trinidad, when they are involved or work within the government or the legal system, it is debatably the terrain they operate in.

Corruption poses possible risks to the goals of overseas operations. Enabling corrupt governments and allowing hatred within our own countries can indicate that we support corrupt governments, and potentially exacerbate security threats within a country. An example was provided of corruption related to the US, ISAF, and NATO operations in Afghanistan, as well as a secret debt of US\$2.2 billion in Mozambique. Examples of cases where corruption occurred within agencies were provided in the case of Aldrich Ames, within the CIA, Robert Hanssen, within the FBI, and Jeffrey Delisie, within the RCN. Another example was provided for corruption in Mozambique, following the donor-designed path to their US\$2.2 billion secret debt deal. Corruption interventions rely on intelligence possibly suggesting that the legal elements of a corruption offence have been satisfied. Key sources of corruption related intelligence include Human Intelligence (HUMINT), Open-source Intelligence (OSINT), and Financial Intelligence (FININT/FINTEL).

Understanding corruption typologies is pertinent for determining what information is actually useful. Additionally, due diligence is needed and suspicious transaction reporting should occur. Financial Institutions (FIs) and 
Designated Non-Financial Business and Professions (DNFBPs) are required to exercise risk-based customer due diligence (CDD) and sanctions due diligence (SDD). These bodies potentially take into account national and international risk factors, products and services, and demographics of a customer base over their lifetime. Where atypical customer behaviour is detected suggesting corruption, a Suspicious Transaction Report (STR) should be prepared and filed.

FIs, which are global institutions that have the potential to access information on parties on both sides of an international transaction, are required to keep records. This requires special recordkeeping, which is more so a requirement for high vulnerability areas.

Various agencies all have potential roles to action. For example, Financial Intelligence Units (FIUs) tentatively engage in tactical, operational, and strategic analysis, which generates reports to be sent to Law Enforcement Agencies (LEAs). LEAs should then utilize specific investigative techniques and engage in possible undercover operations and accessing computer systems. Moreover, intelligence agencies are an integral part of this process as they potentially execute intelligence sharing, investigations, extradition, and asset recovery. Multinational FIs can potentially contribute to building the larger picture of a client's international behaviour. For potential improvement in financial crimes, the profit should be removed from corruption. The process should include actions based on reasonable grounds, balance of probabilities, and lastly, proof beyond a reasonable doubt, for legitimate prosecution to occur. On the other hand, autonomous sanctions can potentially occur when there is reasonable grounds to believe there is a financial crime.

Laws relating to this include Canada's Justice for Victims of Corrupt Foreign Officials Act (Sergei Magnitsky Law), S.C. 2017, c. 21 and USA's Russia and Moldova Jackson-Vanik Repeal, and Sergei Magnitsky Rule of Law Accountability Act of 2012. Generally, sanctions possibly rely on intelligence for targeting selection and to potentially assess their effectiveness. In domestic cases, national risk assessment and sector risk assessments should be considered. The Financial Action Task Force (FATF) could possibly produce a Mutual Evaluation Report (MER) for technical compliance and effectiveness. Additionally, FATF lists should be created, including, High Risk Jurisdictions Subject to a Call for Action, and the FATF "Black List" in most egregious cases. Black and Grey lists should also potentially be updated three times per year. Another type of list are autonomous lists, of which the EU list of high risk third countries and the US Annual INCSR Volume II for Money Laundering are characterized under. 
Key actions that could be taken as discussed in Mr. Dalip's presentation include a clear role of the military in combating corruption at all stages of operations, as this could potentially guide the focus of intelligence agencies. Furthermore, foreign Intelligence Service requires access to new skill sets such as Task force with Security Intelligence Service, Financial Investigation Units, Law Enforcement Units, and the Private Sector (See JMLIT \& AUSTRAC FINTEL Alliance). For this to be potentially effective, compliance professionals must be recruited, and a corruption component should be included in intelligence risk assessments. Finally, corruption vulnerabilities should be a part of screening new and existing staff of intelligence agencies.

\section{Question Period}

In this section, Mr. Dalip discussed the effectiveness of the FATF in governing persons. He began by explaining that answering that question could be potentially controversial. He discussed that there could be situations whereby different results occur, based on context, and that there is no uniformity. You may conduct an action but you are subject to conditions, but conducting the action somewhere else may have different conditions. When asked about how active criminal organizations are at using counter policing tactics or technology. Mr. Dalip explained that infiltration or corruption has possibly been occurring for many years in the law enforcement community. He added that corruption could also possibly involve information and not only money.

Mr. Dalip discussed that intelligence agencies need to be more effective at counter messaging against the actual drivers of terrorism. They possibly need to deepen their understanding of the motivations as to why people desire to commit extremist acts. Finally, Mr. Dalip discussed academic research that he believes is possibly valuable. He explained that information where people chose to leave their life for radicalization would be potentially interesting. More so, why would they leave a safe country to go to a conflict zone or the Levant.

\section{KEY POINTS OF DISCUSSION}

\section{Presentation}

- Corruption Perceptions Index from 2019 indicated that Africa, Asia, South America, and the Caribbean have the highest levels of corruption.

- Corruption can have an impact on national security and possibly affect overseas operations. 
- Intelligence agencies play an important role on detecting corruption to facilitate appropriate legal action.

- Record keeping and information sharing hold potential value to address corruption.

- The military's role in combating corruption at all stages of operations must be clearly defined, as this will guide the focus of intelligence agencies.

- New and existing staff of intelligence agencies should be screened for corruption vulnerabilities.

\section{Question Period}

- Infiltration or corruption has possibly been occurring for many years in the law enforcement community. Furthermore, corruption could involve not only money but information.

- Intelligence agencies need to be more effective at counter messaging against the actual drivers of terrorism. They possibly need to deepen their understanding of the motivations as to why people desire to commit extremist acts.

- More academic research in various topics in intelligence is possibly needed, specifically why people migrate to conflict zones for radicalization.

\section{cc) (†) $\ominus$}

EY NC ND This work is licensed under a Creative Commons AttributionNonCommercial-NoDerivatives 4.0 International License.

(C) (Andrew Dalip, 2021)

Published by the Journal of Intelligence, Conflict, and Warfare and Simon Fraser University

Available from: https://jicw.org/ 